\title{
A Simple Method for Extraction of DNA from Guthrie Cards
}

\author{
Christian Schneeberger, ${ }^{1}$ \\ Fritz Kury, ${ }^{2}$ Jörg Larsen,' \\ Paul Speiser, ${ }^{1}$ and \\ Robert Zeillinger ${ }^{1}$
}

\author{
${ }^{1}$ First Department of Obstetrics \& \\ Gynecology, Molecular Oncology \\ Division, University of Vienna, A-1090 \\ Vienna, Austria; ${ }^{2}$ ViennaLab \\ Labordiagnostika GmbH., A-1110 \\ Vienna, Austria
}

Dried blood samples on filter paper, also known as Guthrie cards, represent easily handled, stored, and shipped resources of analytes such as hormones, proteins, and DNA. PCR-based analysis of DNA extracted from Guthrie cards has been used in different applications such as newborn screening programs, forensic analysis, diagnosis of infectious diseases, and evaluation of mutant allele frequencies. $^{(1-4)}$

Procedures for the extraction of DNA from dried blood spots suitable for use in PCRs have been reported recently. ${ }^{(2,5)}$ Most of these extraction procedures are based upon protein digestion with proteinase $\mathrm{K}$, purification of DNA by extraction with organic solvents, and alcohol precipitation. ${ }^{(1,5)}$ Purified DNA for up to 20 reactions may be obtained by these methods; however, overnight incubation and precipitation steps may be necessary. Also the direct amplification of DNA from dried blood spots has been described. ${ }^{(3)}$ This method has been modified $^{(1)}$ to improve yields of PCR products; however, only one PCR reaction per $4 \times 4$-mm square from dried blood spots may be performed using this method.

Boom et al. ${ }^{(6)}$ have published a method for the purification of nucleic acids from serum and urine that is based upon the fact that in the presence of high concentrations of the chaotropic agent guanidine thiocyanate (GuSCN), nucleic acids will bind to diatoms, silica, or glass particles. Furthermore, GuSCN has been shown to be a powerful agent in the purification of both DNA and RNA because of its potential to lyse cells combined with its ability to inactivate nucleases. ${ }^{(6,7)}$ Here we describe a rapid, simple, and inexpensive microextraction method for the isolation of DNA from dried blood samples that is based on the above-mentioned properties of GuSCN in combination with silica particles. DNA obtained by this method is of sufficient quality and quantity to be used as template DNA in PCRs. We used our extraction method in combination with subsequent PCR and restriction digest of the amplified product for detection of restriction fragment polymorphisms in the retinoblastoma (RB) susceptibility gene. $^{(8,9)}$

\section{MATERIAL AND METHODS Preparation of Buffers}

Lysis Buffer I was $10 \mathrm{~mm}$ Tris- $\mathrm{HCl}(\mathrm{pH}$
8.0), 2 mм EDTA, $50 \mathrm{~mm} \mathrm{NaCl}$, and $2 \%$ SDS. Lysis Buffer II was made by dissolving 120 grams of GuSCN (Clontech, USA) in $100 \mathrm{ml}$ of $0.1 \mathrm{M}$ Tris $-\mathrm{HCl}(\mathrm{pH}$ 6.4 ), and subsequently adding $22 \mathrm{ml}$ of $0.2 \mathrm{M}$ EDTA (pH 8.0), and 2.6 grams of Triton X-100. Wash buffer was made by dissolving 120 grams of GuSCN in 100 $\mathrm{ml}$ of $0.1 \mathrm{M}$ Tris- $\mathrm{HCl}$ (pH 6.4.) TE buffer was $10 \mathrm{~mm}$ Tris- $\mathrm{HCl}$ ( $\mathrm{pH} 8.0), 1 \mathrm{~mm}$ EDTA. As a precaution, GuSCN-containing buffers were prepared in a fume hood and were stable for at least 3 weeks when stored at room temperature in the dark.

\section{Preparation of the Silica Suspension}

Sixty grams of silica $\left(\mathrm{SiO}_{2}, \mathrm{Sigma}, \mathrm{USA}\right)$ was suspended in distilled water in a total volume of $500 \mathrm{ml}$ and sedimented at unit gravity for $24 \mathrm{hr}$ at room temperature. Then, $430 \mathrm{ml}$ of the supernatant was replaced by an equal volume of fresh distilled water, and the silica sediment was resuspended by vigorous shaking. After another sedimentation step ( $5 \mathrm{hr}$ at room temperature), $440 \mathrm{ml}$ of the supernatant was disposed of and $600 \mu \mathrm{l}$ of $\mathrm{HCl}$ $(32 \%, \mathrm{wt} / \mathrm{vol})$ was added to the remaining suspension. The resulting silica suspension was aliquoted in glass bottles, tightly closed, and autoclaved for $20 \mathrm{~min}$ at $121^{\circ} \mathrm{C}$. The suspension was stable for at least 6 months when stored at $4^{\circ} \mathrm{C}$ in the dark.

\section{DNA Isolation}

We used punch pliers to punch 4-mmdiameter circles of dried blood from Guthrie cards (equivalent to a volume of approximately $6 \mu \mathrm{l}$ whole blood) and transferred each circle to a $1.5-\mathrm{ml}$ microcentrifuge tube containing $400 \mu \mathrm{l}$ of Lysis Buffer I. The contents of the tubes were boiled for $5 \mathrm{~min}$, shaken for $5 \mathrm{~min}$ at room temperature, vortexed for 15 sec, and centrifuged for $30 \mathrm{sec}$ at $12,000 \mathrm{~g}$. The whole supernatant was transferred to a new microcentrifuge tube containing $900 \mu \mathrm{l}$ of Lysis Buffer II and $50 \mu \mathrm{l}$ of silica suspension. The reaction mixture was vortexed for $5 \mathrm{sec}$, kept at room temperature for $10 \mathrm{~min}$, vortexed again, and recentrifuged for $15 \mathrm{sec}$. After decanting the supernatant, the silica pellet was completely resuspended in $600 \mu \mathrm{l}$ of wash buffer by vortexing and centrifuging for $15 \mathrm{sec}$. This wash step was repeated one time with wash buffer 


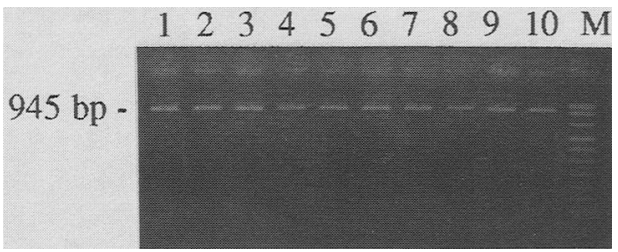

FIGURE 1 PCR amplification of a 945-bp genomic DNA fragment from the RB gene. (Lanes 1-10) $5 \mu$ of PCR product; (lane $M$ ) HincII digest of $\phi X 174$ DNA, electrophoresed in $3 \%$ NuSieve agarose/1\% GTG agarose.

and two times with cold $70 \%$ ethanol. The final silica pellet was dried under vacuum for $15 \mathrm{~min}$. For elution of DNA from silica particles, the pellet was resuspended in $60 \mu \mathrm{l}$ of TE buffer by vortexing, incubating at $56^{\circ} \mathrm{C}$ for 10 min with periodical vortexing, and centrifuging for $2 \mathrm{~min}$. To remove remaining traces of silica, the supernatant was transferred to a new microcentrifuge tube and centrifuged again for $1 \mathrm{~min}$. Ten microliters of the final supernatant was used for PCR.

\section{PCR Amplification}

We carried out PCR in a total volume of $50 \mu \mathrm{l}$ containing: $10 \mu \mathrm{l}$ of silica eluate, 50 pmoles of sense primer (5'-TTCCAATGAAGAACAAATGG-3'), 50 pmoles of antisense primer (5'-GCAATTGCACAATCCAAGTT-3'), $250 \mu \mathrm{M}$ dNTPs (Pharmacia, Sweden), $10 \mathrm{~mm}$ Tris-HCl (pH 9.0), 50 $\mathrm{mM} \mathrm{KCl}, 0.01 \%$ (wt/vol) gelatin, $1.5 \mathrm{~mm}$ $\mathrm{MgCl}_{2}, 0.1 \%$ Triton X-100, and 0.1 unit Hi-Taq DNA Polymerase (ViennaLab, Austria).

PCR was done with a Bio-Med Thermocycler 60 . Amplification cycles were as follows: $92^{\circ} \mathrm{C}$ for $1 \mathrm{~min}, 55^{\circ} \mathrm{C}$ for 2 min, and $72^{\circ} \mathrm{C}$ for $2 \mathrm{~min}$. Thirty amplification cycles were preceded by a primary denaturation step $\left(95^{\circ} \mathrm{C}\right.$ for $\left.3 \mathrm{~min}\right)$ and followed by a final extension step $\left(72^{\circ} \mathrm{C}\right.$ for $5 \mathrm{~min}$ ) after the last cycle.

\section{PCR Product Analysis}

PCR products were precipitated by addition of two volumes of ethanol in the presence of $2.5 \mathrm{M}$ ammonium acetate, centrifuged, washed with cold $70 \%$ ethanol, dried under vacuum, and dissolved in $30 \mu \mathrm{l}$ of the appropriate restriction buffer. Restriction enzyme digestion with 8-12 units of $\mathrm{XbaI}$ (Boehringer Mannheim, Germany) was performed according to the manufacturer's specifications. Following digestion, the samples were electrophoresed in $4 \%$ agarose gels.

\section{RESULTS AND DISCUSSION}

Extracted DNA was sufficiently clean to be readily amplified by PCR. Furthermore, enough DNA could be obtained from 4-mm-diameter circles of dried blood for at least six PCR reactions. More than 150 DNA samples from our laboratory have been successfully prepared by this method. The method allowed sample preparation in less than $1 \mathrm{hr}$ and worked equally well with all samples. Since neither specialized equipment nor specialized knowledge of biochemical techniques is necessary, this method provides a cost-effective and time-efficient procedure for extracting DNA from dried blood samples and may be an al-

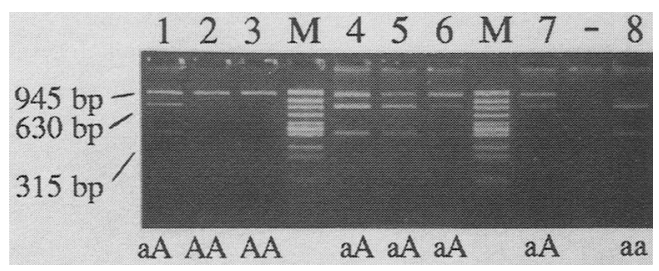

FIGURE $2 \mathrm{XbaI}$ restriction digest of PCR products (lanes 1-8); (lane $M$ ) HincII digest of $\phi X 174$ DNA, electrophoresed in $3 \%$ NuSieve agarose/1\% GTG agarose. The a allele and the A allele correspond to the cut and uncut forms, respectively.

ternative method to other, more timeconsuming and expensive extraction procedures.

We used the procedure in combination with PCR to amplify a 945-bp genomic fragment of the human RB gene containing a polymorphic $\mathrm{XbaI}$ recognition site within intron 17 of the RB susceptibility gene, approximately $21.8 \mathrm{~kb}$ downstream from exon $17^{(8,9)}$ (Fig. 1.). When present, the variable $X b a I$ site is located within the amplified fragment 315 bp from its $3^{\prime}$ end, yielding fragments of $630 \mathrm{bp}$ and $315 \mathrm{bp}$ after $\mathrm{XbaI}$ digestion (Fig. 2.). Allele frequencies, determined from 120 randomly chosen blood samples, were: $a: A=45: 55$. (The a allele and the $A$ allele correspond to the cut and uncut forms, respectively.)

\section{REFERENCES}

1. McCabe, E.R.B. 1991. Utility of PCR for DNA analysis from dried blood spots on filter paper blotters. PCR Methods Applic. 1: 99-106.

2. Rubin, E.M., K.A. Andrews, and Y.W. Kan. 1989. Newborn screening by DNA analysis of dried blood spots. Hum. Genet. 82: 1340-136.

3. Schwartz, E.I., R.C. Khalchitsky, R.C. Eisensmith, and S.L.C. Woo. 1990. Polymerase chain reaction amplification from dried blood spots on Guthrie cards. Lancet ii: $639-640$.

4. McCabe, E.R.B., Y.-H. Zhang, M. Descartes, B.L. Therrell, and H.A. Erlich. 1989. Rapid detection of $b \beta^{\mathrm{s}}$ DNA from Guthrie cards by chromogenic probes. Lancet ii: 741 .

5. Jinks, D.C., M. Minter, D.A. Tarver, M. Vanderford, J.F. Hejtmancik, and E.R.B. McCabe. 1989. Molecular genetic diagnosis of sickle cell disease using dried blood specimens on blotters used for newborn screening. Hum. Genet. 81: 363-366.

6. Boom, R., C.J.A. Sol, M.M.M. Salimans, C.L. Jansen, P. Wertheim van Dillen, and J. van der Noordaa. 1990. Rapid and simple method for purification of nucleic acids. J. Clin. Microbiol. 28: 495-503.

7. Kury, F.D., C. Schneeberger, G. Sliutz, E. Kubista, H. Salzer, M. Medl, S. Leodolter, H. Swoboda, R. Zeillinger, and J. Spona. 1990. Determination of HER-2/neu amplification and expression in tumor tissue and cultured cells using a simple, phenol free method for nucleic acid isolation. Oncogene 5: 1403-1408.

8. McGee, T.L., G.S. Cowley, D.W. Yandell, and T.P. Dryja. 1990. Detection of the Xbal RFLP within the retinoblastoma locus by PCR. Nucleic Acids Res. 18: 207.

9. Wiggs, J., M. Nordenskjold, D. Yandell, J. 
Raysaport, U. Grondin, M. Janson, B. Werelius, R. Petersen, A. Craft, K. Riedel, R. Liberfarb, D. Walton, W. Wilson, and T.P. Dryja. 1988. Prediction of the risk of hereditary retinoblastoma, using DNA polymorphisms within the retinoblastoma gene. N. Engl. J. Med. 318: 151-157.

Received May 26, 1992; accepted in revised form August 3, 1992. 


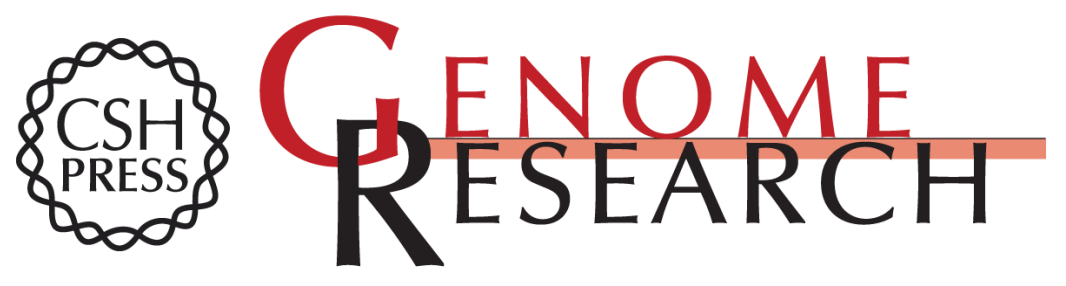

\section{A simple method for extraction of DNA from Guthrie cards.}

C Schneeberger, F Kury, J Larsen, et al.

Genome Res. 1992 2: 177-179

Access the most recent version at doi:10.1101/gr.2.2.177

References This article cites 7 articles, 1 of which can be accessed free at:

http://genome.cshlp.org/content/2/2/177.full.html\#ref-list-1

\section{License}

Email Alerting Receive free email alerts when new articles cite this article - sign up in the box at the Service top right corner of the article or click here.

\section{Affordable, Accurate Sequencing.}

To subscribe to Genome Research go to: https://genome.cshlp.org/subscriptions 